\title{
MANDADO DE SEGURANÇA - JUSTIÇA INCOMPETENTE - SUSPENSÃO DE CONCESSÃO
}

\section{PARECER}

\section{I — INTRODUÇÃO}

1. O Escritório de Advocacia LOURENÇO ADVOGADOS ASSOCIADOS foi contratado, por LIGHT - SERVIÇOS DE ELETRICIDADE S.A., para patrocínio da defesa desta, no processo de ação civil coletiva que lhe foi movida pela DEFENSORIA PÚBLICA DO ESTADO DO RIO DE JANEIRO, por seu Núcleo de Defesa do Consumidor, processo em curso na $8^{a}$ Vara de Falências e Concordatas da Comarca da Capital.

A ação foi ajuizada a propósito de proteção, com base no Código de Defesa do Consumidor, de alegados "direitos individuais homogêneos" de todos os utentes de energia elétrica da referida Empresa, insurgindo-se contra o poder, legal, regulamentar e contratual, que tem esta, como concessionária de serviços públicos federais, de suspensão do fornecimento a usuários inadimplentes ou que tenham praticado fraudes ou furtos na utilização da energia.

2. Foi-nos apresentado, acompanhado da documentação pertinente, o texto da petição inicial de mandado de segurança formulado, para ajuizamento, e no qual são sustentadas violações de direitos líquidos e certos da LIGHT, em decorrência de: (a) falta de jurisdição da Justiça Estadual, a caracerizar sua incompetência absoluta; (b) inadequação da ação proposta; (c) ilegitimidade da DEFENSORIA PÚBLICA; (d) descabimento da tutela antecipada concedida pela MM. Juíza Substituta em exercício no juízo em referência.

3. Os pedidos são de: (I) deferimento de liminar, até decisão final do mandamus, de suspensão do processo e da exigibilidade dos mandamentos decisórios já expedidos, não devendo ser praticados novos atos, no feito, tudo em razão da relevância dos fundamentos apresentados e dos irreparáveis danos que já vêm sendo causados à IMPETRANTE; (II) concessão, a final, do writ, para, declaradas a incompetência absoluta e a nulidade dos atos decisórios, seja ordenado o encaminhamento do feito à Justiça Federal, competente para a causa.

4. Consultam-nos os ilustres patronos que subscrevem a exordial, eminentes colegas, Drs. EVANDRO RAMOS LOURENÇO e EDSON AFFONSO GUIMARÃES, sobre o efetivo cabimento, in casu, do remédio heróico.

\section{II - ASPECTOS PRÉVIOS}

1. Pronunciamo-nos, preliminarmente, em concordância com o teor da peça vestibular, em termos de argumentação e conclusões.

2. A propósito, destacamos os seguintes tópicos, reportando-nos à fundamentação correspondente dos preclaros advogados:

a) competência da Justiça Federal, sendo a UNIÃO FEDERAL e a Agência Nacional de Energia Elétrica - ANEEL litisconsortes passivas necessárias (litisconsórcio unitário) da IMPETRANTE;

b) a ação impugnada é, substancialmente direta de inconstitucionalidade de normas em tese, não se caracterizando a figura dos direitos individuais homogêneos, nem sendo caso de incidência do Código de Defesa do Consumidor;

c) a DEFENSORIA PÚBLICA ESTADUAL exorbitou de suas atribuições, constitucionalmente vinculadas aos necessitados (CF, art. 138), e é, em conseqüência, parte ilegítima;

d) a tutela antecipada, concedida por órgão judicial absolutamente incompetente, e, portanto, nula, é irreparavelmente lesiva; subverte o regime jurídico das concessões federais de energia elétrica, tendo caráter essencial- 
mente normativo: é abusiva. na medida em que próibe. de imediato, a suspensão de fornecimento de energia a usuários inadimplentes. e aos que cometeram fraudes, furtos de energia e outras irregularidades na utilização da energia elétrica; e suspende a exigibilidade dos débitos de consumo irregular ou de utentes em mora; determinando a religação, em curto prazo de todos aqueles que estão sob suspensão: inibe, portanto, poder-dever legal, regulamentar e contratual da IMPETRANTE e prestigia a ilicitude, com inestimável prejuízo para o equilíbrio econômico-financeiro dos serviços e para os usuários adimplentes e honestos.

3. O mandado de segurança se justifica, segundo os patronos, pelo fato de que, tendose a MM. Juíza considerado implicitamente competente, ao despachar a inicial, ordenar a citação da IMPETRANTE, e proferir, de plano, a decisão initio litis, a impugnação, pelos motivos apontados, em que avulta o vício maior da falta de jurisdição do órgão judicial, se dá contra o processo como um todo - para o que inexiste recurso - o qual, no seu conjunto, atinge direitos da IMPETRANTE, inclusive aquele ao juiz natural, e o de efetivação da suspensão do fornecimento, com o ônus de se ver ilegitimamente processada, e de ter de cumprir, de imediato, sob cominações penais e civis, por decisão visceralmente nula, proferida em contexto processual irreversivelmente contaminado, determinações absolutamente abusivas e insuperavelmente danosas, a par das conotações éticas negativas.

4. O cabimento da ação mandamental é que nos compete, por solicitação dos interessados, estudar no presente trabalho.

\section{III - OS MEIOS IMPUGNATIVOS DOS ATOS JUDICIAIS}

1. Os atos processuais podem ser impugnados, por meio de recursos ou de ações.

2. PONTES DE MIRANDA, em seu Tratado da Ação Rescisória das Sentenças e Outras Decisões (Rio, Forense, $5^{\mathrm{a}}$ ed., 1976, p. 643), preleciona que "o juiz pode errar", e “para se corrigirem os erros dos juízes criaram-se os recursos".

Mas acrescenta que "não bastou o reexame dentro da relação jurídica processual": e, por isso. se tem verificado a evolução no sentido de se criarem ou se aproveitarem ações para esse reexame; e "daí a revisão criminal; daí a ação rescisória de sentença e outras decisões".

Em outra obra (Coms. ao CPC, Rio, Forense, 1975, VII: 06), PONTES mostra, uma vez mais, que há impugnativas de atos judiciais que são ações; e há aquelas que são recursos. Os embargos do executado são ações.

Há, portanto, mais meios de impugnação dos atos judiciais, do que os recursos.

3. E aduz, com a proverbial acuidade:

"Na técnica legislativa, quando em evolução, assiste-se, a cada passo, à criação de ações, atividade em que foi cimo de montanha o Pretor, ou à substituição de ação e recurso. Ali, supõe-se falta de remédio jurídico processual, de meio jurídico; aqui, a insuficiência da tutela por meio de recurso. Ali, tudo é 'ex novo'; aqui, novo é, apenas, o meio da ação, a despeito da coisa julgada, ou contra ela."

4. Destarte, o ataque a ato do processo por meio de ação, e não de recurso, é trilha ordinária, e corresponde, como diz PONTES, à superação do pendor do legislador pela via recursal, de modo que, em vez de recurso,

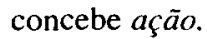

5. Salienta, ainda que, as "mais abrangentes são a ação de mandado de segurança e a ação de habeas corpus", que atacam atos processuais judiciais, e outros fora do contex to processual.

6. A conclusão tranquiila que se pode tirar é que a impugnação de atos processuais, por

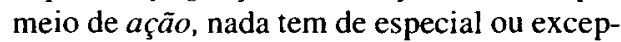
cional, sendo instituição de Direito Comum, tal como o é o recurso.

7. Nesta moldura, enquadra-se o mandado de segurança, juntamente com seu co-irmão, o habeas corpus, e que, a par de sua função de controle e defesa em face de atos executivos e legislativos - sucedendo a um recurso, a apelação extrajudicial —, é, dentro de seu 
balizamento constitucional, meio impugnativo regular de atos judiciais.

\section{IV - A EVOLUÇĀO DO MANDADO \\ DE SEGURANÇA COMO ELEMENTO \\ DE ELUCIDAÇĀO DE SUA ABRANGÊNCIA}

É consabido que o mandado de segurança é o habeas corpus cível, eis que veio suprir a lacuna que existia, no Direito Brasileiro, na defesa de direitos não amparados por aquele.

2. Em nosso País, sempre se buscou a instituição de remédios especiais para o controle da atuação governamental, que, embora coberto, também, pelas açōes comuns, cabíveis, igualmente, quando se trata de litígios entre particulares, precisa de institutos pré-processuais e processuais específicos, dadas as peculiaridades da atividade dos Poderes Públicos e da atuação de controle que o Judiciário exerce sobre ela, a exigir celeridade, imediatidade, pronta atuação, preventiva e repressiva.

3. É que a jurisdição de controle da atividade governamental é segmento específico da função jurisdicional, que interfere na atuação controlada, seja legiferante, seja executiva, hipóteses de heterocontrole, ou própria função judicial, a caracterizar, neste último caso, o autocontrole.

4. A preocupação de juristas e políticos, no sentido da criação de remédios judiciais específicos de controle, adensou-se com o advento da República, quando o Judiciário se tomou efetivamente independente, e assumiu, em toda a plenitude, seu papel de poder controlador da legalidade da atuação pública.

5. O primeiro dos instrumentos surgidos foi a chamada ação sumária especial, criada pelo art. 13 da Lei $n^{\circ} 221$, de 20.11.1894, que fracassou na prática.

Em 1900, a Lei $n^{\circ} 1.185$ permitiu o uso de ações possessórias contra a cobrança de impostos inconstitucionais, tendo essa prática, dentro da tese da existência da 'posse de direitos', sido estendida à defesa de outros direitos públicos subjetivos.
6. A grande contribuição, porém. do Direito Brasileiro, na época. foi chamada doutrina brasileira do habeas corpus, cujo mais expressivo defensor e aplicador, no Supremo Tribunal Federal. foi o Ministro Pedro Lessa, destacando-se, por outro lado, Rui Barbosa, na defesa dos direitos individuais atingidos.

6.1. Esta doutrina tirou partido da redação ampla da Constituição de 1891, que não limitava. pelo menos expressamente, o uso do habeas corpus à defesa do direito de locomoção.

Em seu art. $72, \S 2^{\circ}$, deu, ela em verdade, ao habeas corpus uma feição mais larga do que a tradicional de instrumento de proteção da liberdade de ir, vir e ficar, porquanto prescrevia, de modo vago, que se daria habeas corpus, sempre que o indivíduo sofresse ou se achasse em iminente perigo de sofrer violência ou coação, por ilegalidade ou abuso do poder, sem referência, portanto, à liberdade de locomoção.

6.2. Entendeu-se que esta última era como que um direito-meio, necessário ao exercício de outros direitos, que seriam os direitos-fim.

Assim, ser um funcionário tinha sido demitido ilegalmente, entendia-se que pertinente seria a concessão do habeas corpus, para garantir-lhe o acesso ao serviço, pressuposto necessário do próprio exercício de sua função.

6.3. A Reforma Constitucional de 1926 veio impedir. todavia, o emprego ampliativo do habeas corpus, porquanto reformou a redação do $§ 22$, do art. 72 da Constituição, passando a referir-se, de modo taxativo, à defesa da liberdade de locomoção.

7. Recrudesceram, desse modo, as tentativas de adoção de instrumento processual específico que cobrisse a área não abrangida pelo habeas corpus.

Já em 1914, Alberto Torres, na sua famosa obra "Da Organização Nacional", sugerira a criação do que chamou de mandado de garantia, sob a inspiraçāo, não só dos writs anglo-saxônicos, como também do chamado juicio de amparo, criação do Direito mexicano e que já se expandira para outros países hispano-americanos.

8. Somente, no entanto, a Constituição de 1934, em seu art. 133, inciso 33, veio a criar 
o mandado de segurança, como instrumento de garantia de direitos não protegidos pelo habeas corpus.

9. Desde esse primeiro momento, a tônica foi a de garantia de direitos ameaçados ou violados por inconstitucionalidades ou ilegalidades provindas de qualquer autoridade".

Outrossim, a irmandade com o habeas corpus sempre esteve presente.

Com referência aos atos legislativos, entende-se caber o mandado, quando houver lesão individual decorrente diretamente deles, como ocorre com as leis proibitivas, as de efeitos concretos.

10. A primeira lei reguladora do writ cível a Lei $n^{\circ} 191$, de 16.01.36. já o previa cabível contra atos judiciais (art. $5^{\circ}, \mathrm{I}, c$; e III, a).

A Lei $n^{\circ} 1.533$, de 31.12.51, ainda em vigor, admite o mandado contra despacho ou decisão judicial, quando não haja recurso processual para a hipótese, ou medida correicional modificadora (art. $5^{\circ}, \mathrm{Il}$ ).

11. Completamente afastada a inadequada e minoritária corrente que negava o cabimento do writ contra atos judiciais, embora o admitisse em situações excepcionais, e evolução foi no sentido de sua adoção, quando o recurso não tivesse efeito suspensivo, prevalecendo o entendimento de ser imprescindível a utilização simultânea e tempestiva do writ e do recurso nāo-suspensivo, este, para fastar a preclusão; e aquele apenas para dar efeito suspensivo ao recurso dele desprovido. $O$ ato teria de ser suscetível de provocar dano de difícil ou impossível reparação. O ato judicial era apreciado no julgamento do recurso.

11.1. O mandado de segurança, com essa configuração, tinha caráter cautelar, ancilar, numa deturpação da sua natureza e função (v. nossa posição, na qualidade de Desembargador Federal do TRF-2 ${ }^{2}$ Região, MS $n^{\circ}$ 92.02.15146-6/RJ).

11.2. Em leading case, sempre lembrado no particular, o Ministro XAVIER DE ALBUQUERQUE (STF, Pleno, RE $n^{\circ}$ 76.909-RJ, RTJ 70: 504 e s.), ainda que restritivo quanto a certos aspectos, enumerou pressupostos de cabimento do writ frente $a$ atos judiciais, $\mathrm{e}$ que eram a inocorrência de trânsito em julgado; a inexistência de recurso cabível que ti- vesse. concretamente, efeito suspensivo pleno, e que afastasse todo e qualquer dano ou ameaça de dano: e radical imcompetência ratione materiae ou falta pura e simples de jurisdição, o que é a hipótese 'sub examine' (cf. MILTON FLAKS, Mandado de Segurança: pressupostos de Impetração, Rio. Forense, pp. 183/184).

Entre os casos arrolados, como precedentes, no voto do Relator, está o processamento do feito por juiz sem jurisdição para o caso.

11.3. Atacando. autônoma e diretamente, o ato, julgados sempre houve que dispensam a interposição de recurso em tese cabível, se o ato judicial for manifestamente ilegal ou teratológico: TRF-1 ${ }^{\text {a }}$ Região, MS $n^{\circ}$ 92.01.10230-5, Relatora-Juíza ELIANA CALMON, DJU-II, de 06.08.92, p. 22.905; TRF-2a Região, MS n ${ }^{\circ}$ 92.02.05287-5, Relatora-Desembargadora Federal TÂNIA HEINE, DJU-II, de 13.08 .92 , p. 23.880 ; ou pela inocuidade do remédio recursal ou pela limitação que a exigência envolve à garantia constitucional de acesso à jurisdição: (TRF$3^{a}$ Região, MS nº 118.189, Relatora-Juíza LÚCIA VALLE FIGUEIREDO, DJU-II, de 19.10 .94 , p. 59.699.

Citem-se, ainda, as decisões segundo as quais, independentemente de outros requisitos e pressupostos, cabe a segurança, se houver ilegalidade ou abuso de poder, que ameace ou lese direito líquido e certo. (STJ, RMS $\mathrm{n}^{\circ}$ 97, Relator-Ministro ATHOS CARNEIRO, DJU de 11.12.89, p. 18.140: RMS n ${ }^{\circ} 99$. Relator-Ministro BARROS MONTEIRO, DJU de 19.02.90, p. 1.046 .

11.4. A utilização do writ tinha lugar, muito especialmente, no âmbito do agravo, recurso que, só excepcionalmente, admitia a atribuição de efeito suspensivo; e, assim mesmo, com forte carga discricionária: CPC, art. 558, nas suas versões primitivas.

11.5. A Lei $n^{\circ} 9.139$, de 30.11.95, alterou a redação desse dispositivo, e alargou a atribuição de suspensividade ao agravo, pelo Relator, para generalizá-la aos "casos dos quais possa resultar lesão grave e de difícil reparação, sendo relevante a fundamentação".

11.5.1. Essa suspensão tem a mesma finalidade cautelar, provisória, antes salientada, 
e calcada, como é próprio da espécie, no fumus boni iuris e no periculum in mora.

11.5.2. Passou, então, a predominar, jurisprudencialmente, a tese do descabimento, em princípio, do mandado de segurança para obtenção de efeito suspensivo a recurso sem o mesmo, eis que idêntica função cautelar tinha o writ na espécie, sempre, no entanto, feitas ressalvas.

Nesta linha, CASSIO SCARPINELLA BUENO (Liminar em Mandado de Segurança, São Paulo, RT, $2^{a}$ ed., 1999, p. 299) assinala:

"Assim, a impetração do mandado de segurança contra ato judicial (qualquer que seja este ato) será reservada para aquele caso, em que, efetivamente, sejam descartadas todas as possibilidades de eficácia concedidas pelo sistema processual. Trata-se, em verdade, de reconduzir o mandado de segurança (contra ato judicial) a sua finalidade especifica e constitucionalmente prevista, vedando-se seu uso promiscuamente."

11.6. Sabemos que o objetivo e o alcance das modificações trazidas pela Lei $n^{\circ}$ 9.139/95, se limitam, no máximo, a afastar o citado mandado de segurança cautelar, que objetivava, tão-somente, a obter efeito suspensivo a recurso dele desprovido.

CARREIRA ALVIM (Novo Agravo, BH, Del Rey, 1996, pp. 119/120) história, analisando o art. 558, e seu parágrafo único, na redação da Lei $n^{\circ}$ 9.139/95:

"A suspensão do cumprimento da decisão já era permitida, tendo o novo art. 558 acrescentado às hipóteses anteriores 'outros casos dos quais possa resultar lesão grave e de dificil reparação', desde que 'relevante a fundamentação', com o propósito de esvaziar os mandados de segurança contra ato judicial, no que se tornou pródigo o direito brasileiro.

Como o agravo de instrumento é, em regra, em recurso provido de efeito apenas devolutivo, o mandado de segurança tornou-se a vala comum para imprimir-lhe também o efeito suspensivo, evitando o cumprimento de determinadas decisões que, na prática, importavam em tornar inútil o eventual provimento do agravo, pelo dano de difícil ou impossível reparação que já teriam produzido para o agravante (Barbosa Moreira). No entanto, exige a lei que a lesão que possa resultar do cumprimento seja, a um só tempo, uma lesão grave e de difícil reparação, de modo que não basta apenas uma dessa consequiências, exigindo-se as duas, conjuntamente. À luz da lei, uma lesão grave mas de 'fácil' reparação não autoriza a suspensão, da mesma forma que não a autoriza uma lesão leve de 'difícil' reparação."

Comenta o Autor, em nota de rodapé, que a jurisprudência terá de saber dosar essas situações para evitar iniquiidades.

Neste enfoque de limitações à atribuição de efeito suspensivo ao agravo, a não satisfazer, completamente, o afastamento da lesão provocada pelo ato judicial, cita, ainda, JOSÉ CARLOS BARBOSA MOREIRA, para quem " não há direito do agravante à suspensão, mas poder discricionário do Relator".

11.7. Jamais poderá ser olvidado que o mandado de segurança e o habeas corpus, embora se instrumentalizem através de ações, de remédios jurídicos processuais, são direitos públicos subjetivos, de matriz constitucional: CF, art. $5^{\circ}$, LXVIII e LXIX.

$O$ eminente HELY LOPES MEIRELLES (Mandado de Segurança e Ação Popular, São Paulo, RT, 6 ed., p. 24) é taxativo:

"A só existência do recurso processual cabível não afasta o mandado de segurança, se tal recurso é insuficiente para coibir a ilegalidade do Judiciário e impedir a lesão ao direito evidente do impetrante. Os recursos processuais não constituem fins em si mesmos; são meios de defesa do direito das partes, aos quais a Constituição aditou o mandado de segurança para suprir-lhes as deficiências e proteger o individuo contra os abusos da autoridade, inclusive da judiciária."

E, por isso, coroamos este escorço histórico, com a lição de SERGIO FERRAZ (Mandado de Segurança, São Paulo, Malheiros, $3^{a}$ ed., 1996, p. 101), que sustenta, com propriedade:

"A possibilidade de arrasadora ofensa ou ameaça a direito líquido e certo é muito mais aguda no ato jurisdicional que no legislativo típico ou até mesmo no administrativo. As 
características e os efeitos dos atos jurisdicionais säo de tal natureza que a ilegalidade ou $o$ arbitrio, neles eventualmente manifestados, são suscetiveis de gerar agravos permanentes e irreversíleis - o que raramente se dá, por exemplo, com o ato administrativo. Só por aí já se teria justificação suficiente para uma postura intensamente liberal quan. to à admissão do mandado de segurança contra ato jurisdicional.

O mandado de segurança só deve usar a teoria geral do processo naquilo que não restrinja seu alcance e âmbito de incidência, cunhados exaustiva e totalmente na Lei Maior. E aqui só se diz que se dará mandado de segurança contra ato do Poder Público marcado de ilegalidade ou abuso de poder, violador ou ameaçador de direito líquido e certo. Só! Não há sentido, 'venia concessa', em se invocar teratologias, dano efeito e objetivamente irreparável, ou inexistência de recurso sem efeito suspensivo (e não obstane de obrigatória utilização! Para quê?!), como pressupostos ou condicionamentos à impetração do 'writ' contra ato jurisdicional! Quanto mais quando se trata de 'writ' impetrado por terceiro prejudicado (para o qual o recurso é mera faculdade, e não ônus), o que é também o pensamento de Moniz de Aragão ('Mandado de Segurança contra ato judicial', RT 682:19). Quando assim algum ilustre autor ou douto julgado sustenta, implicitamente está a dizer que as balizas constitucionais da ilegalidade ou do abuso de poder são insuficientes no que toca ao mandado de segurança contra ato jurisdicional! Ora, a verdade é que os mesmos critérios de admissibilidade — porque constitucionais! - e só eles, são exigíveis, qualquer que seja a origem do ato coator. Ou seja, o ato jurisdicional coator não pode ter pautas de admissão diversas das que aplicáveis, por exemplo, ao ato administrativo! É evidente, do que exposto, que não divisamos no mandado de segurança contra ato judicial função meramente cautelar (em contrário: Teori Albino Zavascki, in RePro. 18/181-5). Conosco, em toda essa pauta, Tereza Celina de Arruda Alvim Pinto ('Medida Cautelar, Mandado de Segurança e Ato Judicial', pp. 64 e s.).
Daí nossa opinião: cabe mandado de segurança contra o ato jurisdicional que, praticado com ilegalidade ou abuso de poder, ameace ou viole direito líquido e certo. E só! A irreparabilidade do dano, ou a inexistência de recurso com efeito suspensivo, ou a teratologia ensejada pelo ato, não sāo critérios de admissão em tese do 'mandamus'. Funcionam, sim, como critérios de concessão de medida liminar. Mas tão apenas isso.

A ilegalidade e o abuso no ato jurisdicional existirão seja quando o julgador agir em desconformidade (formal ou material) com a lei. ou quando não agir, quando a tanto legalmente obrigado. Em qualquer desses casos, sem exigências outras, caberá o mandado de segurança."

\section{$V$ - O WRIT EM EXAME}

1. O mandado de segurança, cuja exordial é objeto do presente estudo, enquadra-se. com exatidão, na moldura constitucional - e legal - do writ cível.

2. Funciona ele, precisamente, como uma das ações de impugnação. que, conforme salientado, ao lado e à frente dos recursos, são instrumentos hábeis e pertinentes para a reforma ou cassação de despachos e decisões judiciais.

3. Nada tem a ver com a atribuição cautelar de efeito suspensivo a recursos com eficácia apenas devolutiva; nem é substitutivo recursal.

Nenhuma interferência com ele, a Lei $n^{o}$ 9.139/95.

4. Defende o writ em tela os direitos liquidos e certos, da IMPETRANTE, lesados pela propositura, por parte ilegítima, de ação incabivel, e ajuizada perante Justiça sem jurisdição para a espécie, e, portanto, absolutamente incompetente, que, não obstante. aceitou a ação, despachou a inicial, ordenou a citação da IMPETRANTE e contra ela concedeu tutela antecipada, descabida, intimando-a para cumprimento imediato.

5. A impugnação é, portanto, ao processo como um todo, desde sua origem. 
O que lesa os direitos e legítimos interesses (e esses se enquadram no conceito de direito líquido e certo, para fins de ação mandamental constitucional: TRF-2a Região, AMS $n^{\circ}$ 89.02.03898-O, DJU.II de 04.12.90) é a própria relação jurídico-processual, que já se angularizou, com a citação e a intimação da IMPETRANTE, a qual se vê indevidamente posta como ré, num processo viciado no que há de mais essencial.

Os direitos violados são o de er processada e julgada pelo juiz natural; de ter como parte adversa quem em legitimidade para tal; de ver deduzida em juízo pretensão adequada; ou não ser compelida à ações e omissões que inibem poder-dever legal seu, e de sofrer indevidas ameaças penais e civis.

6. A ilegítima coação sofrida pela IMPETRANTE DECORRE DAS CITADAS ILEGALIDADES, que maculam a ação em si; e pelo abuso de poder, caracterizado pela formação e desenvolvimento da relação jurídico-processual; pela atuação, absolutamente inconstitucional, de órgão da justiça sem jurisdição in casu.

7. O recebimento, indevido, da petição inicial envolve a aceitação, inconstitucional, de uma competência inexistente, o que fere sagrado direito da IMPETRANTE: o de ser processada e julgada pela Justiça a que a Constituição Federal confere o poder jurisdicional, na hipótese.

Não se trata, em verdade, de mera questão de competência, isto é, de repartição de jurisdição; mas de ausência desta, que se distribui constitucionalmente pelas várias Justiças, sendo, no caso, uma delas, a sem jurisdição, da estrutura estadual; e a habilitada, a Justiça Federal, da organização da Uniāo.

8. Mesmo se, no particular, queiramos atender à exigência formulada em situações diversas, da falta de recurso específico, para que possa caber a impetração do mandado de segurança, este pressuposto está preenchido, porquanto a jurisprudência é no sentido de não comportar recurso o despacho que recebe a petição inicial, determinando a citação do réu: STJ, DJU de 04.11.91, p. 15.655.

E PONTES DE MIRANDA (Comentários ao Código de Processo Civil, Rio, Forense,
1974, V: 297) é incisivo, em dizer que o simples "mandar que se distribua e se atue o processo, sem se prevenir que há questão de competência a ser decidida". é conhecer do pedido e "julgar-se, implicitamente competente": "o deferimento do mais simples item da petição inicial... significa suficiente cognição".

9. Assinalemos que há o paralelismo do processo penal, em que não cabe recurso contra a despacho de recebimento da denúncia ou da queixa, mas sim o habeas corpus (JULIO FABRINI MIRABETE, Processo Penal, São Paulo, Atlas, $3^{a}$ ed., 1994, p. 595), que, embora rotulado, pelo CPP, como recurso, é ação mandamental autônoma: no caso, de impugnação (MIRABETE, op. cit., p. 681).

10. Outrossim, o Egrégio SUPERIOR TRIBUNAL DE JUSTIÇA proclama que os despachos e as decisões que surpreendem quem ainda não era parte ré em um processo já em curso; a quem já não esteja neste regularmente representado e atento aos atos judiciais, são perfeitamente impugnáveis pela via mandamental, como meio próprio para corrigir a ilegalidade, no caso inconstitucionalidade (RESP $\mathrm{n}^{\circ}$ 15.298-RJ, DJU de 03.11.99, p. $110)$.

10.1. Quando a IMETRANTE teve ciência do processo, já se viu atingida por um feito deflagrado por uma parte autora ilegítima, que ajuizou uma ação incabivel, a qual foi indevidamente aceita e processada por Juíza sem jurisdição, absolutamente incompetente; e que, desde logo, declarou a inconstitucionalidade de atos federais, expediu mandamentos abusivos, para serem cumpridos, a maioria de imediato, a inibir poderes legais, regulamentares e contratuais da IMPETRANTE; e de religação de todos os úsuários com seu fornecimento suspenso, por inadimplemento, por fraude, por furto de energia, por irregularidades na utilização desta, em exíguo prazo, sob a cominação de sanções cíveis e criminais.

10.2. A questão - a envolver um universo de 3 (três) milhões de usuários - engloba aspectos jurídicos e éticos de magna relevância social, que foram, desde logo, detectados e vergastados, não só pelos meios de comunicação - tanto que a segunda decisão da 
MM. Juíza é uma espécie de "embargos declaratórios" do noticiário do jomal 'O Dia', de grande circulação -, e pelos consumidores adimplentes e em situação regular, que se vêem desprestigiados e sob risco de serem onerados pelo comportamento ilícito e, muitas vezes, criminoso, de outros utentes, que se vêem favorecidos pela impensada, ilegal e inconstitucional postura judicial.

10.3. O efeito-lesivo - para a economia dos serviços por cujo equilíbrio económicofinanceiro a UNIÃO, a ANEEL e a IMPETRANTE são responsáveis — da demanda imprópria, proposta por quem não tem legitimidade para tal, e de comportamento de quem é absolutamente incompetente, é incomensurável.

11. Este quadro evidencia, pois, à outrance, que dificilmente se achará, na realidade do meio judicial, ou na criatividade da doutrina, exemplo mais completo, e acabado de cabimento do writ cível em face de um processo, quer antes, quer depois da Lei $\mathrm{n}^{\circ}$ 9.139/95; $\mathrm{e}$ ainda que se exijam todos os pressupostos e requisitos que os mais rigorosos formulam na matéria.

12. Estão, portanto, cumpridas todas as exigências que fazem os mais limitativos para o cabimento do writ em face da atuação jurisdicional: a da peculiaridade e teratologia da situação; a da presença de dano, não apenas, iminente, mas atual e crescente; a da incompetência absoluta; a da falta de recurso específico que, com plena satisfação, afaste, de imediato, a lesão e ameaças, e deixe inteiramente tranquiilo e a salvo delas a parte.

13. A IMPETRANTE não pede, nem precisa, apenas, obter a suspensão cautelar, provisória, de um determinado despacho ou decisão.

Ela tem o direito, incontestável, liquiido e certo, de não se ver na posição de ré em um processo irremediavelmente inválido na origem.

Seria antijurídico condená-la a essa posição processual, a ter de interpor sucessivos agravos, a cada decisão proferida por quem é absolutamente sem competência, e a presidir um processo irremediavelmente viciado $a b$ ovo.

\section{VI - A INCOMPETÊNCIA ABSOLUTA POR FALTA DE JURISDIÇÃO}

1. Destaquemos o vício maior da incompetência absoluta.

2. É mister grifar que, no caso, não se trata de simples eventual interesse da UNIÃO, por seu Ministério das Minas e Energia, ou da agência autárquica federal, reguladora e fiscalizadora dos serviços públicos de energia elétrica, a $A N E E L$.

2.1. Cuida-se de manifesto caso de inafastável incidência da regra do art. $109, I$, da $C F$, pela caracterização de litisconsórcio passivo unitário da UNIÃO e da ANEEL, com a IMPETRANTE.

2.2. Saliente-se, preliminarmente, que está em questão, unicamente, a esfera federal.

2.2.1. Assim, (a) os serviços públicos de energia elétrica são exclusivos da UNIÃO (CF, art. 21, XII, b); regulados por lei federal que dispõe, especialmente, sobre as concessões federais, a Lei $\mathrm{n}^{\circ} 9.074$, de $07.05 .95 \mathrm{c} / \mathrm{c}$ a Lei $n^{\circ} 8.987$, de 13.02.95, que é a lei nacional geral sobre concessões: pela Lei $n^{\circ} 9.427$, de 26.12.96, que disciplina o regime das concessões federais de serviços públicos de energia elétrica; e por ato administrativo regulamentar federal, a Portaria $n^{\circ} 446 / 97$ ), do artigo Departamento Nacional de Águas e Energia Elétrica, sucedido pela Agência Nacional de Energia Elétrica - ANEEL, autarquia federal instituída pela citada Lei $n^{\circ}$ 9.427/96; (b) a UNIÃO é o Poder Concedente; (c) o contrato de concessão é ato administrativo federal, celebrado entre ela e a IMPETRAN$\mathrm{TE}$, como concessionária, e, portanto, na qualidade de agente da descentralização administrativa federal, ente de colaboração, delegado da Administração Pública Federal; (d) os usuários são utentes federais, isto é, de um serviço público federal, estando as pessoas físicas e jurídicas, que se utilizam da energia, na qualidade de administrados da UNIĀO.

2.2.2. Ainda mais: os pedidos exordiais fundamentais envolvem os da decretação de nulidade, por inconstitucionalidade, do art. $6^{\circ}$, $\S 3^{\circ}$, da Lei $n^{\circ} 8.987 / 95$; o art. 17 da Lei $n^{\circ}$ 9.427/96; os arts. 52, $\S 1^{\circ}, 75$ e 76 da citada Portaria, que hoje tem por titular a ANEEL; 
e a cláusula segunda, subscláusulas segunda e terceira, do contrato de concessão, de que é parte a UNIÃO, pois que este é a base de todas as situações jurídicas em foco: a da UNIÃO, como Concedente; a do concessionário, como seu colaborador, passando a incidir sobre os serviços em tela as disposições legais e regulamentares em referência.

2.3. Destarte, UNIÃO e ANEEL, que são partes de direito material dos atos impugnados, o são, necessariamente, da relação de direito processual em que tais atos são guerreados.

2.3.1. Litisconsortes passivas necessárias da IMPETRANTE, em litisconsórcio unitário, pois que a decisão terá de ser uniforme para todos os atingidos.

E, nesta hipótese, consoante os termos expressos do art. 47 do CPC,

" a eficácia da sentença dependerá da citação de todos os litisconsortes no processo",

o que torna inequívoca a jurisdição da Justiça Federal, pela imprescindível presença da $U N I \bar{A} O$ e da $A N E E L$, no feito.

2.3.2. Enfatizemos que o litisconsórcio necessário unitário exige a presença, no processo, desde o início, de todos os litisconsortes, sob pena de nulidade $a b$ ovo do feito: RSTJ, 89: 132.

3. ARRUDA ALVIM (Manual de Direito Processual Civil, São Paulo, RT, 1977, $\mathrm{I}: 119 / 120)$ faz bem a distinção entre a jurisdição, como poder governamental e instrumental abstrato, cujo exercício se dá através da função jurisdicional; e a jurisdiçāo-competêcia que já é produto da partilha-atribuição desse poder a cada uma das Justiças que compõem o Poder Judiciário da União, o de cada um dos Estados federados e o do Distrito Federal.

\subsection{Explana o festejado processualista:}

"Sabemos que o Poder Judiciário, sobretudo nos Estados modernos, tem, necessariamente, que se subdividir numa multiplicidade de órgãos, dado que, somente assim, é possível ao Estado atender às necessidades de justiça (tutela jurídica) por parte du população.

Já a partir da própria Constituição, por mais de um critério, podemos identificar o que se denomina competência-jurisdição. Através de um critério material (ou seja, pelas conseqüencias jurídico-materiais que o sistema atribui a um fato), ficará o mesmo afeto a uma das Justiças Especiais, isto é, à militar, à eleitoral ou à do trabalho (Constituição, art. 112, III, IV e V). Se a lide não couber, dentro de uma destas (jurisdiçāo-competência), poderá ser da competência da Justiça Federal (Constituição, art. 112, II), havendo interesse da União, autarquia federal ou empresa pública federal (Constituição, art. 125), sejam causas civis ou criminais. Inocorrendo tal interesse cair-se-á na Justiça Comum ("Tribunais e juizes estaduais" Constituição, art. 112,VI). Os problemas da competência, propriamente ditos, ao nível do Código (arts. 86 e s.) pressupōem, porém, que já esteja identificada a Justiça ("jurisdiçãar competência")."

3.2. Como se vê, a falta de jurisdição-competência é questão pré-processual, de direito constitucional, e, mais grave do que qualquer outra forma de incompetência, conduz à inviabilidade da relação jurídico-processual formada na Justiça sem tal jurisdição-competência, e tem de ser declarada de imediato, em qualquer oportunidade e grau de jurisdição, e encaminhado o feito à Justiça que a tenha.

3.3. Assinala, com propriedade, ARRUDA ALVIM, que a jurisdição-competência da Justiça Federal "tem prevalência" sobre as demais Justiças.

$\mathrm{Se}$ a UNIẪO ingressa como assistente ou opoente - Intervenção facultativa de terceiro no processo - , há o fenômeno do deslocamento da competência para a Justiça Federal.

Se é caso de participação necessária, como litisconsorte, a relação jurídico-processual não pode formar-se nem desenvolver-se, e a nulidade não será, apenas, dos atos decisórios, mas de toda a relação.

3.4. O procedimento judicial cabível é o indeferimento da petição inicial, ou, se essa já tiver sido recebida, a extinção do processo, com eficácia ex tunc, por invalidade absoluta; com o encaminhamento, por economia processual, da peça vestibular para a Justiça com jurisdição-competência. 
3.5. É certo, porém, existir o entendimento, mais ortodoxo, de extinção do processo com arquivamento dos autos, tendo o autor, se quiser insistir, formalizar nova propositura da ação, perante a Justiça com jurisdiçāo-competência.

É que as normas constitucionais de cunho impositivo ou vedatório, têm natureza e eficácia muito diversa dos mandamentos positivos ou negativos da legislação infraconstitucional.

Dá-se, em matéria de jurisdição-competência, em confronto com as da competência judicial legalmente fixada, fenômeno da mesma índole que se verifica, na distinção, por exemplo, entre imunidade constitucional e isenção legal.

3.6. Com efeito, nenhum sentido tem, em sistema. como o do ordenamento jurídico brasileiro, igualar a natureza e as conseqüencias de questões de competência estabelecida em um Código de Organização Judiciária, e a jurisdiçāo-competência com matriz na Constituição Federal.

Adite-se que, in casu, outros vícios conduzem à extinção do processo, em razão de indeferimento da inicial: a ilegitimidade 'ad causam', na verdade falta de atribuição da Defensoria Pública; e impropriedade absoluta da ação, pela inadequação da causa peten$d i$, com fundamento em alegada, mas inexistente, relação fornecedor-consumidor do $\mathrm{CDC}$; e da impossibilidade jurídica de, nos termos e na Justiça em que a questão foi colocada, obter-se a declaração de inconstitucionalidade de normas legais e regulamentares.

Verifica-se que a ilegitimidade ad causam e a falta de jurisdição-competência se dão, também, pela legitimação privativa para a propositura de ação direta de inconstitucionalidade (art. 103 da CF); e competência exclusiva, na matéria, do Excelso Pretório.

3.7. Em face dessa pletora de inconstitucionalidades, o cabimento do mandado é inquestionável, mesmo sob o ângulo mais limitativo.

3.8. Mas, ainda que se fique no balizamento da incompetência absoluta ordinária, cabe o writ, devendo citar-se o precedente do Colendo SUPERIOR TRIBUNAL DE JUSTIÇA
(ROMS n 3.758-MG, DJU de 26.04.99, p. 127, Relator-Ministro ANSELMO SANTIA$\mathrm{GO}$ ):

"Crimes praticados por ex-Prefeito. Arquivamento do Inquérito. Incompetência do julgamento monocrático. Art. 29, X, CF/88. Mandado de Segurança para pleitear a nulidade da decisão monocrática. Cabimento.

1. Consoante o disposto no art. 29, X, da Constituição Federal, a competência para julgar Prefeito é do Tribunal de Justiça do Estado, de conseguinte, não detém o Juiz de Primeiro Grau competência para determinar o arquivamento do inquérito processual em que fatos delituosos são imputados a um ex-Prefeito que os teria praticado no exercício do mandato, mostrando-se nula de pleno direito a referida decisão.

2. Não se destinando o mandado de segurança a atacar o despacho que determinou o arquivamento em si, mas sim, a sua ilegalidade, vez que proferido por juiz incompetente, deve ser admitida a impetração sem que tal importe violação à sistemática processual vigente. Recurso provido."

3.9. Por isso, o renomado processualista, JOSÉ DA SILVA PACHECO (Curso de Teoria Geral do Processo, Rio, Forense, 1985, p. 275) é incisivo:

"No caso de competência fixada pela Constituição Federal, entre as diversas justiças especializadas, também chamada competência jurisdicional, trata-se de competencia $a b$ soluta no máximo grau, de modo a que não pode ser alterada pela vontade das partes ou por qualquer outro motivo. $O$ processo instaurado em 'justiça' incompetente é nulo de pleno direito."

3.10. O mandado de segurança, por seu histórico, e por sua configuração constitucional, é o habeas corpus cível, ambas açōes mandamentais de controle da atuação governamental.

3.10.1. Ora, o abuso de poder, a ilegalidade, a coação ilegal, para ambos, caraterizamse, "quando não houver justa causa"; "quando quem ordenar a coação não tiver competência para fazê-lo" e "quando o processo for manifestamente nulo" (CPP, art. 648, I, IV e VI). 
3.10.2. Estando, nestes casos, em questão a relação jurídico-processual como um todo, a concessão do habeas corpus ou do mandado põe termo ao processo, que poderá ser renovado (CPP, arts. 651 e 652); ou, segundo entendimento mais liberal, no aso do writ cível, conforme salientado, já que a Justiça Estadual não tem jurisdição-competência, será a petição inicial - pois que, dela em diante, nada juridicamente existe - encaminhada à Justiça Federal.

4. Quando há falta de jurisdição-competência, a prática de atos judiciais, além do vício da invalidez, caracteriza o chamado abuso de função ou invasão absoluta de função, identificada, exatamente, quando o órgão incompetente e o órgão competente pertencem a Justiças diversas, inclusive, como no caso vertente, a entidades político-federativas diferentes.

É a espécie mais grave de incompetência, tomado este termo, em sentido largo.

\section{VII - DA FALTA DE ATRIBUIÇÃO E DE LEGITIMIDADE "AD CAUSAM" DA DEFENSORIA PÚBLICA ESTADUAL - DA INADEQUAÇÃO DA AÇÃO PROPOSTA - DA CARÊNCIA DE AÇÃO}

1. Falece à Defensoria Pública do Estado do Rio de Janeiro atribuição constitucionaladministrativa e legitimidade processual para a iniciativa judicial que tomou.

2. Não tem, em verdade, a Assistência Judiciária estadual atribuição para, em nome próprio, como instituição local, atuar perante a Justiça Federal.

3. Outrossim, por prescrição constitucional - CF, art. 134 - a Defensoria tem atribuição para a defesa "dos necessitados", pressuposto de legitimidade de sua atuação, reiterada no art. $1^{\circ}$ da Lei Complementar Federal $n^{\circ} 80$, de 12.01.94, que organizou a Defensoria $P \hat{u}$ blica da União e prescreveu normas gerais para a sua organização nos Estados.

4. Subordinadas a este requisito constitucional e legal básico é que se desdobram as funções da instituição, como o patrocínio de ações civis e penais; de defesas judiciais, e o "patrocinar os direitos e interesses do consumidor lesado", indubitavelmente, o 'consumidor necessitado'.

5. Ora, no caso vertente, a ação tem tal amplitude, que abarca todos os consumidores da LIGHT, sejam eles ricos ou pobres; pessoas físicas ou jurídicas; usuários residenciais, rurais, industriais e comerciais, sendo que os das duas últimas categorias nem "consumidores" seriam, mesmo no sentido do Código de Defesa do Consumidor, em que se lastreia o Autor, porquanto, para eles, a energia é um insumo, não se caracterizando a figura do "destinatário final" a que se dirige a defesa assegurada por aquele Código (art. $2^{\circ}$ ).

6. A tanto, certamente, não vai a legitimidade da DEFENSORIA PÚBLICA.

$\mathrm{E}$, também por este motivo, a ação proposta é incabível, caracterizando-se manifesto abuso de poder daquela corporação.

7. Com efeito, o SUPREMO TRIBUNAL FEDERAL, por unanimidade, no julgamento da ADIN n 558-RJ (Medida Cautelar - Tribunal Pleno, 16.03.91; RTJ 146: 434 e s.), reduziu a aplicação do art. 176 (atual 179), $\S 2^{\circ}, V, f$, da Constituição do Estado do Rio de Janeiro, para declarar que o patrocínio, pela Defensoria, dos direitos e interesses do consumidor lesado se limita às hipóteses em que concorra o requisito da necessidade do interessado, suspendendo, por isso, a Suprema Corte, a eficácia do dispositivo, nos demais casos.

8. A ação proposta, porém, não distingue, e a amplitude da ação a torna inviável.

Pretendeu a Defensoria agir em favor de todos os usuários da Ré, sejam eles necessitados ou abastados; sejam eles a PETROBRAS, o Banco do Brasil, o Bradesco, a Companhia Siderúrgica Nacional, a Vale do Rio Doce.

9. Acentue-se, ademais, que, na hipótese, a Defensoria não poderia apresentar-se como legitimada extraordinária, apenas para $o$ subconjunto dos usuários necessitados.

9.1. É que os pedidos formulados nada têm a ver, em verdade, com as ações coletivas para defesa de interesses individuais homogêneos, ao contrário do que procura fazer crer o Autor. 
9.2. Primeiramente, não estão em jogo tais 'interesses ou direitos individuais homogêneos', porquanto não há direitos (não há direito a praticar ilicitudes e a não sofrer os ônus correspondentes), nem, muito menos, direitos que decorram de fato comum, isto é, de fato ou de conjunto de fatos concretos comuns a consumidores. como há de se entender a cláusula legal (art. 81, parágrafo único, III, do CDC) "decorrentes de origem comum", que simplesmente reproduz o vetusto aforismo "ex facto oritur ius'.

9.3. Ao contrário, a causa petendi não se lastreia em fatos concretos, mas, diversamente, envolve regras in abstracto.

Em verdade, o que se pediu é, substancialmente, a revogação de normas legais e regulamentares federais e a impossível criação judicial de regras diversas, em absoluto conflito com aquelas.

10. Como se ataca o regime legal, regulamentar o contratual, em tese, e no seu todo, inexiste possibilidade de fracionamento do conjunto, tanto assim que a ação foi proposta para benefício de todo esse.

11. Como se viu, a presente ação é inadequada, mas, mesmo para as que são válidas, o Ministério Público é que é a instituição que tem condições de atuar em nome de toda a coletividade de usuários.

12. Todo o conjunto de pedidos exordiais se baseia na alegação de inconstitucionalidade de dispositivo legal ( $a r t .6^{\circ}, \S 3^{\circ}$, da Lei federal $n^{\circ} 8.987 / 95$ ) e preceitos regulamentares (arts. 52, $\S 1^{\circ}, 74$ e 76 da Portaria $n^{\circ}$ 466/97 do Ministério das Minas e Energia), que conferem ao concessionário dos serviços públicos de energia elétrica o poder de suspender o fornecimento aos usuários inadimplentes e que pratiquem ilicitudes na utilização da energia.

É pedido explícito da DEFENSORIA a declaração da nulidade dessas regras federais.

13. Nesta modelagem, a ação se apresenta como de declaração de inconstitucionalidade de normas legais e regulamentares federais, pelo que se mostra inviável, pela falta de legitimidade do Autor, pela impossibilidade jurídica do pedido e pelo errôneo direciona- mento competencial, privativa que é a jurisdição da suprema Corte Nacional.

14. Outrossim, a ação ajuizada pela defensoria, conforme sabemos, está designada como ação civil coletiva para defesa de direitos individuais homogêneos, com base no Código de Defesa do Consumidor, contido na Lei $n^{\circ} 8.078$, de 11.09.90, art. 81, parágrafo único, III.

14.1. Além das observações já formuladas a respeito, uma anotação a ser necessariamente feita é a de que o Código em pauta não se aplica à hipótese.

14.2. Efetivamente, a Lei $n^{\circ} 8.078 / 90$ contém, apenas, um dispositivo sobre a prestação de serviços públicos, o art. 22, e seu parágrafo único, que cuidam, exclusivamente, da qualidade dos serviços.

Os demais preceitos da Lei dirigem-se aos consumidores nas relações de mercado, foro econômico da iniciativa privada; e não às relações entre usuários e prestadores de serviços públicos, que são objeto de legislação específica, como prevê o art. $37, \S 3^{\circ}$, da Constituição Federal.

14.3. O art. 175, parágrafo único, da Carta Magna Nacional, robustece a natureza própria da relação jurídica utente-concessionário, inclusive no campo específico dos

"direitos dos usuários",

que é objeto de lei (que o dispositivo prevê) especifica sobre concessöes.

14.4. Ora, as duas leis federais sobre concessões de serviços públicos - a geral, Lei $n^{\circ}$ 8.987/95; e a específica dos serviços de energia elétrica, a Lei $n^{\circ} 9.427 / 96$ - são de mesmo nível hierárquico-normativo do Código de Defesa do Consumidor, mas muito posteriores a ele; e ambas, expressamente, autorizam a suspensão do fornecimento.

Assim, quer porque, pertencendo ao mesmo patamar eficacial do ordenamento jurídico brasileiro, são ulteriores; quer pelo seu caráter especial, prevalecem as citadas Leis, sobre o CDC: Lei de Introdução ao Código Civil, art. $2^{\circ}, \S \S 1^{\circ}$ e $2^{\circ}$.

A causa petendi, isto é, a que título se pede, é, pois, imprórpia, pois usuário de serviço público não é consumidor do mercado econômico. 
15. Também pelo vício em tela, cabe o mandado de segurança em estudo.

\section{VIU - CONCLUSÃO}

1. Reiteremos que estão em questão vícios ligados à incompetência absoluta por ausência de jurisdição, falta de atribuição e ilegitimidade da DEFENSORIA, e à inadequação da ação, a refletir em elemento fundamental, no caso, do regime juridico das concessões, qual seja o poder-dever, do concessionário, do prestador do serviço, de suspender o fornecimento aos usuários inadimplentes, fraudadores e praticantes de furto de energia e de outras irregularidades na utilização desta.

A ação é coletiva, objetivando, portanto, todo o universo dos usuários de um serviço público federal.

Seu pedido é, em verdade, de declaração em tese da incontitucionalidade das regras citadas, e, aliás, por isso, se chamou a juízo, também, a CERJ - Companhia de Eletricidade do Rio de Janeiro, em litisconsórcio, eis que sujeita às mesmas regras, único ponto em comum entre as duas concessionárias (art. 46, IV, do CPC), que têm, em verdade, área de concessão, usuários e sede inteiramente diversos.

2. Sublinhemos, uma vez mais, que não interessaria dizer-se, para tentar afastar a pertinência do mandado de segurança que cabe agravo contra a decisão tutelar de antecipação, e que aquele poderá vir a receber eficácia suspensiva.

2.1. Não seria suficiente, porquanto a ilegalidade e o abuso de poder apanham o processo como um todo, e manter-se-ia o gravame da situação de ré, em um feito totalmente viciado; com os ônus que esta condição acarreta, a par da lesão atual, vultosa e irreparável que as decisões tomadas vêm acarretando, sempre sob as cominações cíveis e criminais.

2.2. É a posição clássica de PONTES DE MIRANDA (Coms. ao CPC, Rio, Forense, $2^{\mathrm{a}}$ ed., V: 173), pela qual não interessa saber se há recurso com ou sem efeito suspensivo, se não se afasta "a inquietação ao direito certo e líquido".

Se não há a completa eliminação da ofensa ou retirada da ameaça, é intentável o mandado de segurança.

3. Os pedidos do mandado são, nos termos do exposto, pertinentes:

a) a competência para a causa é da Justiça Federal;

b) a DEFENSORIA PÚBLICA em geral, $e$, de modo especial, a do ESTADO, não tem atribuição para atuar, na hipótese, sendo, carecedora de ação, dada, inclusive, a total inadequação da ação proposta;

c) destarte, sendo inviável está, a consequiência é o indeferimento da petição inicial;

d) a todos esses obstáculos, somar-se-ia, de qualquer modo, a impropriedade do pedido e, consequientemente, da concessão, de tutela antecipada.

4. Por seu turno, a suspensão ex tunc do processo, é medida, initio litis, necessária, e consentânea com a eficácia de preservação dos direitos da IMPETRANTE, em face da gravidade dos vícios pré-processuais e processuais apontados; das lesões já em curso e que progressivamente se vão irreversivelmente potencializando.

Realce-se, mais uma vez, a argüição de falta de jurisdição-competência, de incompetência absoluta.

É de encampar-se, com segurança, a lição, invocada na inicial, do sempre lembrado CELSO AGRÍCOLA BARBI, que afirmou, com razão, que essa argüição, a envolver a nulidade da relação jurídico-processual, leva à suspensão do feito, com maior força de razão do que a exceção de incompetência relativa, que tem esse efeito.

5. Concluímos, portanto, com a tranqüila assertiva do perfeito cabimento do mandado de segurança em foco.

Rio de Janeiro, 22 de dezembro de 1999.

SERGIO DE ANDRÉA FERREIRA

Advogado e Professor Titular no Rio de Janeiro

OAB-RJ $n^{\circ} 79.890$ (OAB-GB $\left.n^{\circ} 11.417\right)$. 